Article

\title{
Corporate governance disclosure and corporate performance of Nigerian banks
}

\author{
Wilson E. Herbert ${ }^{*}$, ThankGod C. Agwor ${ }^{2}$ \\ 1 Dept. of Banking and Finance, Faculty of Management Sciences, Federal University, Otuoke, \\ Bayelsa State, Nigeria; weherbert12@gmail.com \\ 2 Dept. of Accountancy, Faculty of Management Sciences, Rivers State University, Port Harcourt, \\ Nigeria; tagwor@yahoo.com \\ * Correspondence: weherbert12@gmail.com; Tel.: +2348036025258
}

Received: 6 May 2021; Accepted: 11 June 2021; Published: 13 June 2021

\begin{abstract}
Corporate disclosure is a key mechanism of corporate governance. This study examined the effect of corporate governance disclosure (CGD) on the financial performance of commercial banks listed on the Nigeria Stock Exchange. Based on the provisions of the Code of Corporate Governance for Public Companies in Nigeria, 2011 and the Code of Corporate Governance for Banks and Discount Houses 2014, the study developed a disclosure checklist and employed content analysis technique to extract corporate governance (CG) from 78 annual reports of 13 Nigerian commercial banks from 2011 to 2016. The study trichotomized CGD into those relating to the board of directors, risk framework, and whistleblowing policy. The results of the hypothesized relationships showed a positive and significant association between CGD and the banks' financial performance, with a positive effect of CGD on the board of directors and whistleblowing policy. However, the study did not find a significant association between CGD of risk management framework and the banks' financial performance. This study contributes to the body of knowledge by providing a broader understanding of the effect of CGD on banks' financial performance. The development of a disclosure checklist based on the regulators' codes of corporate governance is a useful addition to the literature.
\end{abstract}

Keywords: Corporate Governance; Corporate Governance Codes; Corporate Governance Disclosure; Nigerian Banks; Nigeria.

JEL codes: G3; G30

\section{Introduction}

Very few topics have elicited as much consensus in national and international business conversations as corporate governance. Over the years, there has been a concerted interest around the world in promoting good governance in corporate organizations and Governments, and public-sector agencies. Good corporate performance is typically associated with accountable and transparent governance structure or good government with accountable and transparent systems of political and economic governance. The history of corporate governance proceeded from a global concern for more efficient management of publicly quoted (listed) companies in the face of growing concerns about inadequate protection of shareholders' rights and interests by corporate management. Another global trigger was the ostensible apathy of large corporate organizations towards wider stakeholder interests (that is, beyond shareholder wealth maximization) amidst growing anxieties about the failure of corporate social responsibility and environmental concerns. Recent corporate scandals and failures have attracted mainstream interest in the wake of economic crises as policymakers, business leaders 
and the general public comprehend the economic consequences of incomplete or inadequate disclosure of information in corporate financial reports. While there has been a flurry of a national and global regulation to mitigate the scourge, the prudential measures have, nevertheless, not gained much mileage in stemming the tide of the harmful impact of fraudulent corporate governance disclosure on the stability of systemically important corporations.

Corporate governance is the institution of structures, processes, and rules that guide and ensure that organizations are properly managed to the benefit of all stakeholders. It is about maintaining an appropriate balance of accountability among three key players: the owners of the company (as principals), company executives (employed as the owners' agents - the directors/managers), and the company executives and third parties, including other stakeholders. ${ }^{1}$ This characterization is somewhat different from that of Shrivastav and Kalsie (2017). Effective corporate governance provides corporate stability which, in turn, supports economic progress and development. In well-governed entities, directors (and managers) exhibit competence and care, financial propriety, honesty and integrity, transparency and accountability, adherence to good ethical standards and relevant laws, regulations, and policies, and commitment to enhancing shareholders' value and protection of interests of stakeholders. Corporate governance is dynamic and constantly looking for new rules and regulations, structures, and practices for the benefit of all stakeholders. The involvement of boards is to ensure that truly good and progressive governance subsists to instill ethical standards and best practices that add corporate value and prevent or minimize corporate infractions.

Several national and multilateral organizations have weighed in with their positions on corporate governance in the wake of the spate of recent corporate financial scandals and collapses which necessitated a coordinated global response to improvements in the quality of corporate governance architecture and associated disclosure. Important multilateral agencies that both identified and offered global insights into corporate governance deficits include the Organization for Economic Cooperation and Development (OECD) (1999, 2004), UNCTAD (2003), World Economic Forum (WEF) (2003), and UN Global Compact (UNGC) (2009). For example, in arriving at its consensus of what constitutes good corporate governance, published as 'elements of corporate governance, the OECD scanned the views of stakeholders from many different countries. The OECD canvasses the view that "the primary role for regulation is to shape a corporate governance environment compatible with societal values that allows competition and market forces to work so that corporations can succeed in generating a longterm economic gain. Specific governance structures or practices will not necessarily fit all companies at all times" (OECD, 1999, 2004). The OECD identified seven (7) key elements of good corporate governance as (i) the rights and obligations of shareholders; (ii) equitable treatment of shareholders; (iii) the role of stakeholders and corporate governance; (iv).transparency, disclosure of information and audit; (v) the board of directors; (vi)-non-executive members of the board; (vii)·executive management, compensation and performance (OECD, 1999, 2004).

Corporate governance issues do not arise in a vacuum. Rather, they stem from an identifiable process. Contemporary corporate governance is traceable to the UK Cadbury Report of 1992. The Cadbury Committee, named after its chairman, Adrian Cadbury, was established in May 1991 sequel to several high-profile corporate collapses. The primary mandate of the Committee was to evolve mechanisms to protect weak and widely dispersed shareholders against the opportunistic proclivity of directors and managers. Corporate governance is architected on four fundamental pillars of agencyrelated concern: (a) the increasing lack of investor confidence in the managerial stewardship (honesty and accountability deficit) of listed companies; (b) financial collapses of public corporations; (c) the negligence of auditors cum lack of faithful representation of facts in audited accounts and the potential loss of a self-regulatory role of auditors; and (d) lack of board's accountability over such matters as directors' remuneration (See: Cadbury, 1990, 2000).

1 "Stakeholder groups are by definition those that have something at stake in the organization, operational activities, subsistence and/or collapse/failure of the organization. ... Although the nature and size of stakes may vary considerably from the company (group) to company (group), the existence of stake per se is sufficient to warrant a particular stakeholder group in an open society to expect and receive the opportunity to provide input into or interrogate activities that affect or potentially affect it and to exert some control for the group's overall interest" (Herbert, 1996; Herbert, Nwaorgu, Onyilo, and Iormbagah, 2020). 
These concerns gravitate to a failure to attenuate the schism between shareholders and directors (shareholders' representatives responsible for setting policies, strategies, and governance systems and overseeing management) and managers (who implement board policies). The involvement relations of corporate governance are the triad of shareholders and the ownership pattern, directors and the board composition, and management, in the order of the principal-agent model. These principal actors, their interests, and interactions are embedded in what is known as the 'corporate governance triangle' (EWMI/PFS Program, 2005). Both insightful analyses and public perceptions in Sub-Saharan Africa (SSA) suggest the prevalence of governance deficit in public and private sectors, where officials commit flagrant breaches of public trust through opacity in governance and contract awards and opportunistic procurement of public works and services. Poor governance attenuates the institutional capacity of organizations, hamper performance, distort and weaken markets, and impede economic development, trade, and investment.

A review of the disclosure literature indicates a heavy focus of prior studies on the determinants of disclosures (Wallace, Naser, and Mora, 1994; Wallace and Naser, 1995; Owusu-Ansa, 1998; Bujaki and McConomy, 2002; Ho and Wong, 2001; Camfferman and Cooke, 2002; Street and Gray, 2002; Daske and Gebhardt, 2006; Haniffa and Cooke, 2002; Barako, 2007; Samaha and Dahawy, 2011; Samaha, Dahawy, Hussainey and Stapleton, 2012). While there is a burgeoning literature on the nexus between corporate governance and corporate disclosure, empirical attention to the relations between CG mechanisms and financial performance is still inchoate, especially in developing countries and more so in SSA where cultural rigidities, institutional laxity, weak legal and regulatory structures, prebendal politics in executive and board appointments and/or political interference, jointly or separately affect corporate activities (See: (Herbert, Tsegba, Ene. and Onyilo, 2017; Herbert, 2019)). To be sure, highlevel (board and management) appointments in public and large corporate organizations are of secondary importance or relevance only to the extent that the appointees protect or vouch to protect the basic interests of the appointing authority or facilitators of the appointments. For the most part, merit is thrown out of the window where other considerations prevail.

Given the vital role banks play in national and global economic development, this study examines the effects of voluntary disclosure of corporate governance practices on the financial performance of 13 NSE-listed banks in Nigeria over the six years, 2011 to 2016. The paper proceeds as follows. Section 2 overviews the literature on corporate governance (CG) and CG disclosure (CGD). The research hypotheses are also formulated therein. Section 3 presents the data and methodology. Section 4 discusses the results while Section 5 concludes the paper.

\section{Literature Review}

\subsection{Manifestations of Corporate Governance Disclosure (CGD) Infractions}

The spirit in which CGD infractions manifest adumbrates the agency theoretic problem. It represents the framework of the organizational failure of corporate governance in the context of the disclosure. Corporate governance disclosure (CGD) infractions encompass a wide range of principalagent problems, including (i) false disclosures; (ii) misstatements in financial statements; (iii) internal control failures; (iv) market abuses; (v) corporate governance lapses such as poor board oversight, irregular approval of directors' remuneration, unjustified disbursements to directors and management of the company, related party transactions not conducted at arm's length and their non-disclosure in financial statements and other kinds of insider abuses such as abnormal deductions and payment of dividends above the statutory requirement; (vi) delinquent tax compliance, including non-remittance of deductions at source to appropriate tax authorities; (vii) complexity and opacity of company's operations and lack of clarity in company's structure; and (viii) perpetual lateness in filing annual returns. Some of these occur conjunctively or separately. For example, material misstatements in financial statements and material internal control deficiencies are contemporaneous with false disclosures, market abuses, and corporate governance lapses. Most corporate failures exhibit red flags of these governance kinds before their occurrence. 


\subsection{Codification of Corporate Governance Guidelines in Nigeria's Financial Sector}

Conceptually, a corporate governance disclosure (CGD) is a relevant statement or information about a firm's corporate governance policy and actions taken in response thereof which is released to the public to guide or influence investment or stakeholders' decisions. It is the action of releasing relevant information to the public about a firm's corporate governance policies and practices. In the disclosure, the statement or information first identifies the relevant CG policies of the firm or organization and, then states the firm's responsory practices thereto. To improve corporate governance, the Securities and Exchange Commission (SEC), in September 2008, set to review the 2003 Code of Corporate Governance for public companies in Nigeria, address the perceived weaknesses in public companies, and improve the mechanism for enforceability of the codes. The 2011 SEC Code was aimed at strengthening the 2008 codes as well as engendering the highest standards of transparency, accountability, and good corporate governance, without unduly inhibiting enterprise and innovation.

Before the 2004/2005 banking consolidation, there were 89 banks in Nigeria. The banks were largely characterized by a low capital base, insolvency and illiquidity, overdependence on Government (public sector) deposits, foreign exchange arbitrage trading, poor asset quality, and weak corporate governance. The banking consolidation brought radical changes to the nature, structure, and modus operandi of banking operations in Nigeria. (See also: (Barros and Caporale, 2012)). Sequel to the banking consolidation, the CBN promulgated the 2006 CBN CG Code (CBN-CCG), which was later replaced by the 2014 Code for banks and discount houses. Besides the CBN and SEC Codes of Corporate Governance, the Financial Reporting Council of Nigeria (FRCN) issued the Nigerian Code of Corporate Governance (NCCG) in 2018, which replaced all existing sectorial Codes of Corporate Governance in Nigeria. All public companies mandatorily comply with the requirements of these Codes to putatively enhance good governance practices, engender public confidence to attract investments, and promote efficiency and transparency in the market and financial institutions. Table 1 presents a genealogy of Corporate Governance (CG) Codes in Nigeria.

Presently in Nigeria, there are 22 commercial banks (or what is commonly referred to as deposit money banks (DMBs)). Eight of these have an international authorization, to wit: Access Bank Plc, Fidelity Bank Plc, First City Monument Bank Plc (FCMB), First Bank Nigeria Limited, Guaranty Trust Bank Plc, Union Bank of Nigeria Plc, United Bank of Africa Plc (UBA) and Zenith Bank Plc. The international authorization implies that these are multinational financial institutions with international banking services that provide customers with different services both nationally and internationally as part of their scheduled services. Eleven of the 22 commercial banks operate under the national authorization, namely: Citi Bank Nigeria Limited, Eco Bank Nigeria Plc, Heritage Bank Limited, Keystone Bank Limited, Polaris Bank Plc, Stanbic IBTC Bank Plc, Standard Chartered Bank Plc, Sterling Bank Plc, Titan Trust Bank Limited, Unity Bank Plc, and Wema Bank Plc. The remaining three commercial banks operate under regional authorization, that is, they operate as regional banks. These are Suntrust Bank Nigeria Limited, Providus Bank Plc, and Globus Bank.

Table 1. Corporate Governance (CG) Codes in Nigeria

\begin{tabular}{ccccc}
\hline S/N & CG Codes & Year & Industry & Mandatory/Voluntary \\
\hline 1. & PenCom Code (PenCom-CCG) & 2008 & Pensions & Mandatory \\
\hline 2. & NAICOM Code (NAICOM-CCG) & 2009 & Insurance & Mandatory \\
\hline 3. & SEC Code (SEC-CCG) (Replaced 2003 & 2011 & Public companies & Mandatory \\
& Code) & & Banks and Discount & Houses \\
\hline 4. & CBN CG Code (CBN-CCG) (Replaced & 2014 & Telecommunications & Mandatory \\
\hline 5. & $\begin{array}{c}\text { Nigerian Communications Commission } \\
\text { (NCC) CCG (Replaced 2014 Code) }\end{array}$ & 2016 & Mandatory \\
\hline 6. & $\begin{array}{c}\text { Nigerian Code of Corporate Governance } \\
\text { (NCCG) (Replaced FRC 2006 NCCG) }\end{array}$ & 2018 & Private sector companies & \\
\hline
\end{tabular}




\subsection{A Preliminary Statement of the Voluntary Disclosure Framework}

Voluntary or discretionary disclosure issues have been the focus of an increasing amount of research since the 1970s when information disclosure or transparency in corporate reporting surfaced in response to the burgeoning awareness of the agency problems associated with the divergence of interests between diverse ownership and corporate management. The awareness became acute with the rapid growth of multinational enterprises (MNEs) and their power to control and move resources internationally, often at the detriment of host countries' national interests (Herbert, 1995). In consequence, the rise of nationalism brought trade unions and governments on the same page in demanding greater transparency, accountability, and information disclosure from the MNEs. Thus, from the 1980s to date, there has been a flood of research into the dynamics and ramifications of voluntary disclosure (See, for example: (Gray, Shaw, and McSweeney, 1981; Verrecchia, 1983, 2001; Jennings and Starks, 1985; Herbert, 1987; Meek, Roberts and Gray, 1995; Vishwanath and Kaufmann, 1999; Ho and Wong. 2001; Healy and Palepu, 2001; Bamber, Jiang, \& Wang, 2010)). Two things bear emphasizing about the triad of corporate accountability, corporate transparency, and corporate disclosure. First, both in the national and international contexts, the triad is influenced by a variety of economic, social, and political factors (Gray, Shaw, and McSweeney, 1981). Second, in the context of corporate information, the triad refers to disclosure of information in published financial reports according to the Generally Accepted Accounting Principles (GAAP) and International Financial Reporting Standards (IFRS) and the related Codes of Corporate Governance, such as CBN codes (for banks and finance houses) and SEC Codes (for public companies).

Voluntary disclosure models are discretionary in nature and can be analyzed from two interrelated hypotheses, namely: a hypothesis about when to disclose, and a hypothesis about the degree of information quality. Likewise, the director's (beholder's) discretionary power is twofold: discretion to choose the point of disclosure, and discretion to choose the degree of information quality (Verrecchia, 1983, 2001; Jennings and Starks, 1985; Herbert, 1987). The threshold level of disclosure is that point, whether in degree, level, or time, at which the firm chooses to disclose voluntary information or chooses to withhold the same (Herbert, 1987). In effect, the threshold level of disclosure is a limiting level below and above which disclosure produces a marginal reaction.

\subsection{Theoretical Framework}

Several theoretical frameworks have been employed as explanatory candidates for voluntary corporate disclosure. However, theorization in most corporate disclosure research has mainstreamed into four interrelated perspectives: agency theory, stakeholder theory, legitimacy theory, and signaling theory. These can be broadly classified as social and political theories which offer better insights into and satisfactory explanations of disclosure practices than economic-based models. The conventional assumptions and political considerations surrounding extant accounting disclosures can broadly be rationalized as empirical attempts to understand and explain accounting practices from an integrative conclave of social and political theories. The term 'integrative' defines the accounting strategy or political influences of accommodating different shades of opinions and interests in the attempt to find a consensus theoretical resolution that satisfies multiple stakeholders, including shareholders, regulators, governments, and the society at large. The integrative process is an assembly of strong theoretical candidates that have profound explanatory power or influence. While the theories provide sufficient rationale for corporate disclosure, a considerable relationship exists between the theories for corporate practices.

\subsubsection{Agency Theory Perspective}

The agency theory (Jensen and Meckling, 1976) offers a framework that links corporate disclosure behavior to firm-specific characteristics. Corporate governance mechanisms are introduced to control or mitigate the agency problem and ensure that directors act not just in the interests of shareholders but all stakeholders. The agency perspective of CGD creates a dichotomy of interrelationships: the 
internal and external governance mechanisms. The internal ecosystem of corporate governance comprises issues that are within the circle of influence and control of the firm, that is those focal areas the board has control over and can act upon. The external governance mechanisms, on the other hand, are concerned with issues that are essentially outside the circle of control and influence of the firm (the board). External stakeholders, as they are perceived, include the firm's external market, government, regulatory bodies, and their rules and regulations and other externalities. External governance mechanisms are imposed on and/or controlled by those outside the firm and serve the objectives of government, policymakers, regulators, tax authorities, industry/trade union associations, and institutional compliance agencies. External stakeholders illuminate the character traits and practices of good corporate governance and use their eclectic industry experiences and interactions to illustrate authentic guidelines and comparative corporate governance practices. Corporate governance mechanisms ensure that directors pursue economic efficiency by minimizing transaction costs. The agency theory is architected as an alternative variant of the transaction cost theory.

\subsubsection{Stakeholder Theory Perspective}

Ordinarily, few businesses will trade the pursuit of profit maximization (or shareholder wealth maximization) for stakeholder-wide interest pursuit or ethical balancing of sustainability of the environment and society (Herbert, Nwaorgu, Onyilo and Iormbagah, 2020). Stakeholder theory is anchored on the notion that firms exist at the pleasure of society, reinforcing McKinsey \& Company's 2020 (Vivian Hunt, Bruce Simpson, and Yuito Yamada) report that "corporations exist with the permission of society, and any sector can be regulated out of business." The CGD aims to provide a framework to fully disclose the extent to which the firm has embedded the culture of good corporate governance and complied with the codes of CG during a given period. In recent times, multiple voices have raised global consciousness about stakeholder capitalism as experience shows that "most boards have not sufficiently grappled with the significant implications [of stakeholder capitalism] for their organizations" (Huber, Leape, Mark, and Simpson, 2020). This perspective was reinforced at the January 2020 World Economic Forum (WEF) at Davos that also marked the 50th anniversary of the Forum, where the world leaders were united on the need for a new kind of capitalism, known as stakeholder capitalism, to provide new, more diverse and inclusive governance architecture in the way organizations conduct their activities. As a result, corporate governance, with comprehensive corporate disclosure, has changed profoundly, in terms of attitude towards more inclusive stakeholder interests, including environmental, social, and governance (ESG) disclosure.

\subsubsection{Legitimacy Theory}

Legitimacy theory is another framework for explaining and predicting CGD practice. The premise of the legitimacy theory is that an organization is a nexus of social contracts with various stakeholders and, as such, its objective pursuits are putatively to fulfil such diverse contractual relationships, as opposed to traditional business focus on short-termism and its preoccupation with short-term results for shareholders. A company loses its legitimacy if it habitually violates its social contract with its community of stakeholders. This phenomenon referred to as the 'legitimacy gap', can result in "legitimization threats" (Fernando and Lawrence, 2014). The legitimacy theory of CGD raises the moral ground of business activity beyond shareholder wealth maximization to include wider stakeholder interests and considerations of what Suchman (1995) describes as "a generalized perception or assumption that the actions of an entity are desirable, proper or appropriate within some socially constructed system of norms, values, beliefs, and definitions". The thrust of the legitimacy theory is that the globalized world with the integration of national markets and economies has compelled a new paradigm or business model that (a) acknowledges a diverse group of stakeholders with different and conflicting interests, (b) wittingly recognizes a social contract between a firm and society, and (c) accentuates business policies and practices that are beneficial for all stakeholders (Darnall, Henriques, and Sadorsky, 2010). In effect, the legitimacy theory provides an understanding of a firm's behavior in developing, implementing, and reporting its CG performance through a CGD framework. 


\subsubsection{Signalling Theory}

The discretionary disclosure hypothesis draws heavily from the signaling literature and the assumptions that underlie it and informational asymmetry. The common theme of this theory is that information is a signal which reveals (or obscures) the true liquidating value of a firm perturbed by some noise (Verrecchia, 1983, 2001). Signaling theory is employed in a variety of economic transactions to describe corporate behavior in the presence of asymmetric information or what Williamson (1975) tersely characterizes as 'information impactedness'. Ethically-minded managers with inside information will be predisposed to use CGD to signal information to stakeholders about their CG practices (for example, economic, environmental, and social performance of their firms), thereby enhancing the reputation of the firm. Such specific disclosures could be used as a valued-statement signal to convey truly good governance (good CG-compliant status) or CG-friendly firms from poor CG practice (CG-unfriendly) firms. Signaling has triggered enormous literature attention and application in many decision scenarios in a range of disciplines outside accounting and finance to anthropology and zoology (Bird and Smith, 2005). In essence, signaling theory is fundamentally concerned with reducing information asymmetry between two or more parties to a given set of actual or prospective transactions (Spence, 1973, 2002).

\subsection{Empirical Review}

There is a large and growing literature about different dimensions and contexts of corporate governance and corporate reporting and disclosure (See, for example: (Healy and Palepu, 1993, 2001; Verrecchia, 1983, 2001; Wallace, Naser, and Mora, 1994; Wallace and Naser, 1995; Owusu-Ansah, 1998; Botosan, 1997; Dockery and Herbert, 2000a, b; Dockery, Herbert and Taylor, 2000; Herbert, 2001; Mitton, 2002; Arun and Turner, 2002a, b; Baek, Kang and Park, 2004; Refait-Alexandre, Farvaque, Garnet, and Saïdane, 2009; Bhasin, 2010; Herbert and Tsegba, 2011; Jiao, 2011; Subramanian and Reddy, 2012; Dockery, Tsegba, and Herbert, 2013; Tsegba and Herbert, 2013a, b; Tsegba, Herbert and Ene, 2014; Dembo and Rasaratham, 2014; Emmanuel and Sabastian, 2015; Gyamerah, Amo and Adomako, 2020; Soyemi, Afolabi and Obigbemi, 2021)). The attention of this section is limited to the literature on the nexus between dimensions and contexts of corporate governance disclosure and financial performance. For example, Emmanuel and Sabastian (2015) investigated the relationship between corporate governance disclosure (CGD) practices and performance of Nigerian banks, with a set of corporate governance indicators derived from 10 listed banks in the NSE from 2000-2009. They found CGD to be positively associated with performance, whereby banks with higher disclosure profiles posted better results than banks with lesser disclosure.

Mitton (2002) analyzed the impact of corporate governance on the East Asian crisis and reported that firms with higher disclosure quality had better stock price performance. Similarly, Baek, Kang, and Park (2004) reported that firms with higher disclosure quality experienced greater stability, (that is, suffered less), from the shock of the Korean crisis. Jiao (2011) documented a significantly positive association between corporate disclosure rankings, market valuation, and firm performance. Corporate disclosure also affects the cost of capital (See, for example: (Botosan, 1997; Sengupta, 1998)) and on market valuation of financial expertise on audit committees of boards of directors (DeFond, Hann and Hu, 2005). Hassan, Romilly, Giorgioni, and Power (2009) examined the value relevance of disclosure in the Egyptian capital market and observed a positive but insignificant relationship. They argued that the statistical insignificance might be due to the interplay of different causal factors in the equation of disclosure and firm value. Wagenhofer (2004) posits that the effects of disclosure depend on three factors: uncertainty, multi-person settings with conflicts of interest, and information asymmetry. Othman (2012) examined the impact of board structure and process disclosure level on corporate performance in the emerging African markets and reported a significant positive relationship, with the effect more pronounced amongst Anglophone African firms than their Francophone counterparts. The author also found evidence of colonial heritage influence. 
Ntim, Kwaku, and Danbolt (2012) examined the effects of CGD differences in the shareholder versus stakeholder dichotomy and whether the differences explain the variations in the market value of South African firms. Their results confirmed a positive association between CGD practices and firm value, with the effect of CG provisions stronger for shareholders than for other stakeholders. Collett and Hrasky (2005) examined the relationship between the voluntary disclosure of information about corporate governance practices and the intention to raise external finance, using corporate governance disclosures in the annual reports of Australian companies in 1994. They found a positive association of voluntary disclosure of corporate governance information to raise equity capital, but not intending to raise debt capital. Achoki, Kule, and Shukla (2016) examined the effect of voluntary disclosure on the financial performance of 14 Rwandan banks over the period of 2011 to 2016 . They observed that variations in voluntary disclosure had an explanatory effect on financial performance.

Other studies, such as Brown and Caylor, 2006; Kohlbeck and Mayhew, 2010; Al-Akra and Ali, 2012, have shown that enhanced CGD practice improves firm value. For instance, Brown and Caylor (2006) show that some corporate governance provisions are positively associated with firm value. Disclosure influences firm value via two mechanisms: impact through firm risk, and expected future cash flows (Lang, Lins and Miller, 2003; Al-Akra and Ali, 2012). The burgeoning literature notwithstanding, the microanalytic frameworks, confounding ownership structures and conflicting disclosure results in these studies affirm a lack of consistent evidence (Hassan, Romilly, Giorgioni and Power, 2009). The interplay of different determinants of the relationship between disclosure and firm value implies that there is some scope for improvement in the level of corporate governance standards and quality of corporate disclosures (See, for example: (Hassan, Romilly, Giorgioni, and Power, 2009; Bhasin, 2010; Tsegba and Herbert, 2013a, b). The present study seeks to join the literature in espousing the relationship between corporate governance disclosure and firm performance, within the context of the Nigerian banking industry. We also bring into the mainstream conversation of corporate governance the complementarity of hindsight, oversight, foresight, and insight in broadening our understanding of and/or shaping corporate governance practices.

\subsection{Development of Research Hypotheses}

\subsubsection{Corporate Governance Disclosure of Board of Directors and Financial Performance}

The board of directors is the custodian of corporate governance of its organization and formulates the firm's strategic policies and plans and exercises ultimate responsibility for accountability, performance, and disclosure. The buck of corporate governance stops on the board's table (MD or Chairman). The board of directors' corporate governance disclosures illuminates the board practices, including board composition and structure to facilitate monitoring by stakeholders. This shapes their perception of how well or otherwise the firm is governed. Research shows that there is a nexus between the governance of firms and their levels of disclosure, such that those better-governed firms make more informative disclosures (Beekes and Brown, 2006). Although a variety of market value ratios are available, the most popular include earnings per share (EPS), return on equity (ROE) and return on assets (ROA). Each of these measures is used differently, but when combined, they offer a broad financial portrait of the firm. In addition, these market value ratios give management an idea of what a firm's investors think of its performance and prospects. Thus, we formulate the following general null hypothesis.

H01: Corporate governance disclosure of board of directors (CGDBD) has no significant effect on the financial performance of banks (ROA, ROE, and EPS, respectively). This general hypothesis is decomposed into the following three hypotheses. Financial performance is proxied by ROA, ROE, and EPS.

H01A: Corporate governance disclosure of board of directors (CGDBD) has no significant positive effect on return on assets (ROA) of Nigerian banks. 
H01B: Corporate governance disclosure of board of directors (CGDBD) has no significant positive effect on return on equity (ROE) of Nigerian banks.

H01C: Corporate governance disclosure of board of directors (CGDBD) has no significant positive effect on earnings per share (EPS) of Nigerian banks.

\subsubsection{Corporate Governance Disclosure of Risk Framework and Financial Performance}

The SEC (2011) and the CBN (2014) recommend that banks should adopt effective risk management practices at every level to help safeguard and create shareholder value. An effective risk mitigation policy develops strategies and programs for risk prevention, detection and deterrence, and risk disclosure. Corporate governance risk management framework (CGRMF) seeks to (a) increase the economic efficiency of the bank's operations by decreasing leakages caused by internal control failure of error, fraud, or corruption, (b) diminish the bank's overall exposure to various kinds of risks, (c) enhance the bank's capacity to sustain these risks that may hamper or reduce its daily operations, and (d) enhance the depositors', political and international support for the bank's programs. The CGDRMF promotes risk awareness, operational and strategic decision-making, including internal control, the level of commitment and support of the board, management, and employees in assessing, responding, and controlling risks as well as mitigating regulatory scrutiny and attendant regulatory costs (Meulbroek, 2002). Thus, the following general null hypothesis is formulated.

H02: Corporate governance disclosure of risk management (CGDRM) has no significant positive effect on the financial performance of banks (proxied by ROA, ROE, and EPS, respectively). This general hypothesis is disaggregated into the following three hypotheses.

H02A: Corporate governance disclosure of risk management (CGDRM) has no significant positive effect on the return on assets (ROA) of Nigerian banks.

H02B: Corporate governance disclosure of risk management (CGDRM) has no significant positive effect on the return on equity (ROE) of Nigerian banks.

H02C: Corporate governance disclosure of risk management (CGDRM) has no significant positive effect on earnings per share (EPS) of Nigerian banks.

\subsubsection{Corporate Governance Disclosure of Whistle Blowing Policy and Financial Performance}

Banking operations are characterized by a variety of unethical practices such as fraud and corruption, insider dealing, and expropriation of minority shareholders (Sanusi, 2010). Whistleblowing has emerged as an effective anti-fraud and anti-corruption policy measure, adopted by national and multilateral governments, including the United Nations (Stachowicz-Stanusch and Wankel, 2011; Robert, 2014; Herbert, 2019). The global popularity of whistleblowing is such that Fortune 500 companies include it in their antifraud policy initiatives to enhance integrity, transparency, and accountability. Whistleblowing is the reporting by employees or anyone with intimate knowledge of, or useful information about, suspected misconduct, illegal acts, or related suspicions or violations of a fraudulent nature (Herbert, 2019). The policy entails disclosure by persons with subterranean or inside knowledge of illegal, immoral, or fraudulent practices perpetrated against an organization or government to the relevant authority with capacity to institute appropriate action (see also: (Micelli and Near 1992; Micelli, Near, and Dworkin, 2008)). A company institutes a whistleblowing policy to embolden employees and others to avail it of their serious concerns about the ethical implications of the firm's activities. The disclosure of whistleblowing policy is likely to engender trust and confidence in staff, management, and stakeholders in general, and thus boost financial performance and firm value. Thus, the following null hypotheses are formulated.

$\mathrm{H}_{3 \mathrm{~A}}: \quad$ Corporate governance disclosure of whistle-blowing policy (CGDWB) has no significant positive effect on the return on assets (ROA) of Nigerian banks.

$\mathrm{H}_{3 \mathrm{~B}}$ : Corporate governance disclosure of whistle-blowing policy has no significant positive effect on return on equity (ROE) of Nigerian banks. 
$\mathrm{H}_{3}$ : $\quad$ Corporate governance disclosure of whistle-blowing policy has no significant positive effect on earnings per share (EPS) of Nigerian banks.

\subsubsection{Moderating effect of control variables of size and block-holding}

Bank size and block shareholding are used as moderator variables in this study, the objective being to determine their effect on the direction and/or strength of the relation between the dependent and independent variables. The null hypothesis of no significant effect is posed.

$\mathrm{H}_{4}$ : Bank size and block shareholdings have no significant moderating effect on the financial performance of banks.

\section{Data and Methods}

The data consist of 78 annual observations (reports) of 13 Nigerian banks, from $1^{\text {st }}$ January 2011 to $31^{\text {st }}$ December 2016, which were obtained from the Fact Book of the NSE (Appendix 1). The latter contained the required information for the 13 banks listed on the NSE, covering the 6 years. The choice of this period was to ensure data availability and to account for the developments in these variables. Besides, with the enforcement of the corporate governance codes by the NSE, data from 2011 onwards were used because in subsequent years NSE regulations influenced listed companies to make disclosures about their corporate governance practices. The empirical specification is a content analysis evaluation process of CG data in the annual reports of the banks from where CG disclosure indices were then constructed (Appendix 2). The use of content analysis is consistent with the disclosure literature (Wallace, Naser, and Mora, 1994; Gray, Kouhy and Lavers, 1995; Hackston and Milne, 1996; Botosan, 1997; Haniffa and Cooke, 2002; Barako, 2007; Herbert, Nwaorgu, Onyilo and Iormbagah, 2020). For a company's annual reports, content analysis entails a systematic perusal and codification of the body of texts, narratives, images, and other symbolic presentations of the company into various contextual categories, based on predefined criteria. The study adopted the (OLS) regression to estimate the parameters of the relationship between CGD and financial performance.

\subsection{Test for normal distribution (Table 2)}

We performed the Shapiro-Wilk normality test to confirm if the sample comes from a population with a normal distribution. Small values of the test indicate that the sample is not normally distributed, and the null hypothesis of the normal distribution is rejected. If the value of the Shapiro-Wilk test (W) is greater than 0.05 , then the null hypothesis is not rejected, and the data are deemed to be normal. If the $\mathrm{W}$-value is below 0.05 , it signifies a significant deviation of the data from a normal distribution, and the null hypothesis is rejected. As table 2 demonstrates, the $\mathrm{W}$-values of all the models and their associated p-values are greater than 0.05 in each case. They fail to reject the null hypothesis and thus confirm that the data exhibit a normal distribution.

Table 2. Shapiro-Wilk W Normality Test

\begin{tabular}{cccccc}
\hline Model & Variable & No. of Observations & $\mathbf{W}$ & $\mathbf{Z}$ & p-value \\
\hline 1A & ROA & 78 & 0.96980 & 1.549 & 0.06067 \\
\hline 1B & ROE & 78 & 0.98504 & 0.013 & 0.49489 \\
\hline 1C & EPS & 78 & 0.98866 & -0.594 & 0.72374 \\
\hline 2A & ROA & 78 & 0.96951 & 1.571 & 0.05814 \\
\hline 2B & ROE & 78 & 0.97971 & 0.680 & 0.24835 \\
\hline 2C & EPS & 78 & 0.98492 & 0.030 & 0.48783 \\
\hline 3A & ROA & 78 & 0.97613 & 0.035 & 0.15036 \\
\hline 3B & ROE & 78 & 0.98657 & -0.223 & 0.5818 \\
\hline 3C & EPS & 78 & 0.98660 & -0.238 & 0.59404 \\
\hline
\end{tabular}

Note. $\mathrm{H}_{0}=$ The data are from the normal distribution. Reject $\mathrm{H}_{0}$ if $\mathrm{p}$-values are $<0.05$, otherwise accept. 


\subsection{Breusch-Pagan Test for Heteroskedasticity (Table 3)}

A fundamental assumption of the OLS is homoskedasticity, that is, the variance of the error term is constant. The Breusch-Pagan test is used to detect any linear form of heteroskedasticity. The null hypothesis is that of equality of the error variances. A large or small chi-square indicates the presence or absence of heteroskedasticity, respectively. The p-value of the chi-squared test with the null hypothesis was rejected for $\mathrm{p}$-value $<0.05$. In this case, the null hypothesis of homoskedasticity is accepted for all the models.

Table 3. Breusch-Pagan test for heteroskedasticity

\begin{tabular}{cccc}
\hline Model & Variable & $\boldsymbol{\chi}^{\mathbf{2}} \mathbf{( 1 )}$ & p-value \\
\hline 1A & ROA & 0.02 & 0.8958 \\
\hline 1B & ROE & 0.00 & 0.9844 \\
\hline 1C & EPS & 2.36 & 0.1242 \\
\hline 2A & ROA & 0.14 & 0.7115 \\
\hline 2B & ROE & 0.11 & 0.7368 \\
\hline 2C & EPS & 3,86 & 0.1151 \\
\hline 3A & ROA & 0.01 & 0.9037 \\
\hline 3B & ROE & 0.08 & 0.7815 \\
\hline 3C & EPS & 0.24 & 0.6208
\end{tabular}

Note: $\mathrm{H}_{0}=$ The the error variances are all equal. Reject $\mathrm{H}_{0}$ if $\mathrm{p}$-value $<0.05$; otherwise accept. The models and variables are as specified in hypotheses $1 \mathrm{~A} \ldots 3 \mathrm{C}$.

\subsection{Durbin-Watson Test for Serial Correlation (Table 4)}

The Durbin-Watson test was done to detect the presence of autocorrelation or serial correlation in the residuals from the regression analysis and to assess the strength of the relationship between the variables. Contextually, the autocorrelation of the residuals is bad and signifies that the data points are not correlated well enough to support or justify the model. The null hypothesis is that the residuals from OLS regression are not autocorrelated or serially correlated. As Table 4 evinces, there is no evidence of autocorrelation in the models.

Table 4. Durbin-Watson Test for Serial Correlation

\begin{tabular}{ccc}
\hline Model & Durbin-Watson d-statistic & Decision \\
\hline Model 1A & 1.26076 & No serial correlation \\
\hline Model 1B & 1.29009 & No serial correlation \\
\hline Model 1C & 1.438852 & No serial correlation \\
\hline Model 2A & 1.484307 & No serial correlation \\
\hline Model 2B & 1.467621 & No serial correlation \\
\hline Model 2C & 1.555818 & No serial correlation \\
\hline Model 3A & 1.462178 & No serial correlation \\
\hline Model 3B & 1.424731 & No serial correlation \\
\hline Model 3C & 1.515349 & No serial correlation \\
\hline
\end{tabular}

$\mathrm{H}_{0}=$ the residuals from an OLS regression are not serially correlated. The value of D-W statistic ranges from $0-4$.

\subsection{Variance Inflation factor and Multicollinearity checks}

Multicollinearity exists when the independent variables are themselves correlated. The variance inflation factor (VIF) and its reciprocal, tolerance, are two closely related statistical tools for diagnosing multicollinearity in a regression model. Table 5 exhibits a summary of the VIF and tolerance values. A correlation between the independent variables is considered undesirable for multivariate analysis only if it exceeds 0.8 (Barako and Tower, 2006; Tsegba and Herbert, 2013a). The VIF for all the variables is 
less than 2, which is far less than 10 considered harmful for regression analysis (Gujarati and Sangeetha, 2007). Tolerance ranges from 0 to 1, where high tolerance (e.g., 0.84) implies low multicollinearity while low tolerance (e.g., 0.19) suggests high (serious) multicollinearity (Glen, 2018). The VIF and tolerance values affirm that multicollinearity is not a concern in this study.

Table 5. Variance Inflation Factor (VIF)

\begin{tabular}{|c|c|c|c|c|c|c|}
\hline \multirow[t]{2}{*}{ Variable } & \multicolumn{2}{|r|}{ Model 1} & \multicolumn{2}{|r|}{ Model 2} & \multicolumn{2}{|r|}{ Model 3} \\
\hline & VIF & Tolerance (1/VIF) & VIF & Tolerance (1/VIF) & VIF & Tolerance (1/VIF) \\
\hline CGDBD & 1.44 & 0.693059 & & & & \\
\hline CGDRMF & & & 1.04 & 0.963812 & & \\
\hline CGDWBP & & & & & 1.74 & 0.574208 \\
\hline SIZE & 1.31 & 0.765494 & 1.04 & 0.959810 & 1.48 & 0.673663 \\
\hline BLOCK & 1.15 & 0.869072 & 1.08 & 0.926002 & 1.23 & 0.816014 \\
\hline Mean VIF & 1.30 & & 1.05 & & 1.48 & \\
\hline
\end{tabular}

The VIF measures how much multicollinearity exists in a regression model. Higher values denote multicollinearity, which could negatively impact the regression model, vice versa.

\section{Results}

Table 6 presents the regression results of the nexus between CGD of Directors and ROA, ROE, and EPS. The results are partitioned into three models, $1 \mathrm{~A}$ to $1 \mathrm{C}$, indicating in each case the statistical relationship with bank performance, proxied by ROA, ROE, and EPS, respectively. Model 1A shows that the relationship between corporate governance disclosure of board of directors (CGDBD) and ROA is positively significant at the $5 \%$ level ( $\mathrm{p}$-value $=0.024$ ). This contrasts with the a priori expectation, which means that the null hypothesis $\left(\mathrm{H}_{01 \mathrm{~A}}\right)$ is sustained. Model $1 \mathrm{~B}$ indicates a positive coefficient on CGDBD. Though the direction is not as predicted, the relationship (Но1в) is not statistically significant $(\mathrm{p}$-value $=0.165)$, leading to the acceptance of the null hypothesis. Model $1 \mathrm{C}$ reports a positive and statistically significant coefficient on CGDBD ( $\mathrm{p}$-value $=0.009$ ), which fails to reject the null hypothesis (Ho1c). The model includes bank size and block shareholdings as control variables. Bank size projects positive coefficients across the models. The positive effect is statistically significant in models 1B and 1C. While model 1A records a positive coefficient on block shareholding, models $1 \mathrm{~B}$ and $1 \mathrm{C}$ present negative coefficients. In all three models, the influence of block shareholding is insignificant.

Table 6. OLS Regression of CGD Score on Directors and Bank Performance (ROA, ROE, and EPS)

\begin{tabular}{cccccccccc}
\hline & \multicolumn{3}{c}{ Model 1A (ROA) } & \multicolumn{2}{c}{ Model 1B (ROE) } & \multicolumn{3}{c}{ Model 1C (EPS) } \\
\hline Variable & Coef. & t-statistic & $\begin{array}{c}\text { p- } \\
\text { value }\end{array}$ & Coef. & $\begin{array}{c}\mathrm{t}- \\
\text { statistic }\end{array}$ & $\begin{array}{c}\text { p- } \\
\text { value }\end{array}$ & Coef. & $\begin{array}{c}\mathrm{t}^{-} \\
\text {statistic }\end{array}$ & $\begin{array}{c}\mathrm{p}^{-} \\
\text {value }\end{array}$ \\
\hline CGDBD & 82.504 & 2.30 & 0.024 & 48.0663 & 1.40 & 0.165 & 81.738 & 2.68 & 0.009 \\
\hline Size & 4.566 & 1.79 & 0.77 & 6.29392 & 2.58 & 0.012 & 7.803 & 3.60 & 0.001 \\
\hline Block & 6.843 & 0.63 & 0.530 & -5.41191 & -0.52 & 0.603 & -4.602 & -0.50 & 0.619 \\
\hline Intercept & -119.81 & -2.47 & 0.016 & -126.078 & & -2.71 & -183.239 & -4.44 & 0.000 \\
\hline Observations & 78 & & & 78 & & & 78 & & \\
\hline F (3, 74) & 5.29 & & 0.002 & 6.00 & & 0.0010 & 14.21 & & 0.000 \\
\hline R-squared & 0.177 & & & 0.196 & & & 0.365 & & \\
\hline
\end{tabular}

Table 7 displays the results of the three models on the relationship between corporate governance disclosure of risk management framework (CGDRMF) and bank performance (ROA, ROE, and EPS). Model 2A indicates that CGDRMF is positively related to ROA. However, this relationship ( $\left.\mathrm{H}_{02 \mathrm{~A}}\right)$ is not statistically significant $(\mathrm{p}$-value $=0.184$ ), leading to the acceptance of the null hypothesis. Model 
$2 \mathrm{~B}$ of the table shows a positive but statistically insignificant effect with a p-value of 0.623 . Thus, the null hypothesis $\left(\mathrm{H}_{02 B}\right)$ of no significant effect on ROE is accepted. Model $2 \mathrm{C}$ presents the result of the test of the effect of CGDRMF on EPS ( $\mathrm{H}_{02} \mathrm{C}$ ). The result confirms a positive but insignificant effect ( $\mathrm{p}$ value $=0.246$ ). Thus, the null hypothesis $\mathrm{H}_{02}$ is upheld.

Table 7. OLS Regression of CGD Score on Risk Management and Bank Performance (ROA, ROE, and EPS)

\begin{tabular}{llllllllll}
\hline & \multicolumn{3}{c}{ Model 2A (ROA) } & \multicolumn{3}{c}{ Model 2B (ROE) } & \multicolumn{3}{c}{ Model 2C (EPS) } \\
\hline Variable & Coef. & t-stat & p-value & Coef. & t-stat & p-value & Coef. & t-stat & p-value \\
\hline CGDRMF & 52.795 & 1.34 & 0.184 & 18.4150 & 0.49 & 0.623 & 39.7313 & 1.17 & 0.246 \\
\hline Sze & 7.115 & 3.06 & 0.003 & 7.80092 & 3.54 & 0.001 & 10.3508 & 5.16 & 0.000 \\
\hline Block & -3.603 & -0.34 & 0.738 & -10.8572 & -1.07 & 0.289 & -14.2987 & -1.54 & 0.127 \\
\hline Intercept & -151.651 & -2.60 & 0.011 & -134.929 & -2.44 & 0.017 & -204.904 & -4.07 & 0.000 \\
\hline Observations & 78 & & & 78 & & & 78 & & \\
\hline F (3, 74) & 3.97 & & 0.011 & 5.310 & & 0.0023 & 11.41 & & 0.000 \\
\hline R-squared & 0.1386 & & & 0.177 & & & 0.3163 & & \\
\hline
\end{tabular}

\subsection{OLS Regression of CGD Score on Directors and Bank Performance}

Table 8. Effect of Size and Block holdings on the Relationship between CGD and Bank Performance

\begin{tabular}{lllllllllll}
\hline & \multicolumn{3}{c}{ Model 3A (ROA) } & \multicolumn{3}{c}{ Model 3B (ROE) } & \multicolumn{3}{c}{ Model 3C (EPS) } \\
\hline Variable & Coef. & t-stat & p-value & Coef. & t-stat & p-value & Coef. & t-stat & p-value \\
\hline CGDWBP & 49.9861 & 2.28 & 0.025 & 37.4411 & 1.80 & 0.076 & 62.6491 & 3.46 & 0.001 \\
\hline Size & 3.82300 & 1.41 & 0.164 & 5.29702 & 2.06 & 0.043 & 6.17729 & 2.75 & 0.007 \\
\hline Block & 9.04160 & 0.81 & 0.422 & -2.48191 & -0.23 & 0.816 & .177824 & 0.02 & 0.985 \\
\hline Intercept & -75.0545 & -1.48 & 0.144 & -94.1611 & -1.95 & 0.054 & -129.67 & -3.09 & 0.003 \\
\hline Observations & 78 & & & 78 & & & 78 & & \\
\hline F (3, 74) & 5.26 & & 0.0024 & 6.52 & & 0.0006 & 16.50 & & 0.0000 \\
\hline R-squared & 0.1756 & & & 0.2091 & & & 0.4008 & & \\
\hline
\end{tabular}

Table 8 shows the results of the effect of corporate governance disclosure of whistle-blowing policy (CGDWBP) on bank performance. Model 3A indicates a significantly positive effect at the $5 \%$ level $(\mathrm{p}$-value $=0.025)$. This leads to a rejection of the null hypothesis $\left(\mathrm{H}_{03 \mathrm{~A}}\right)$. Model 3B shows a positive and significant relationship, in which case the null hypothesis $\left(\mathrm{H}_{0 з \mathrm{~B}}\right)$ is rejected. Model $3 \mathrm{C}$ also indicates that corporate governance disclosure of whistle-blowing policy (CGDWBP) is positively and significantly related to earnings per share (EPS). Thus, H0зс is rejected. In respect of the control variables, bank size has a positive moderating effect on the relationship between CGD and the financial performance of banks. However, this effect is only significant in models $3 B$ and $3 C$, which is concerning ROE and EPS. Block shareholdings present mixed results across the models. While models $3 \mathrm{~A}$ and $3 \mathrm{C}$ record positive coefficients, model $3 \mathrm{~B}$ shows a negative coefficient which indicates an inverse relationship. In effect, all the relationships are not significant.

\section{Discussion of Findings}

The model numbers relate to tables 6 to 8 above. Model 1A (Table 6) indicates that a one-percent increase in the disclosure of corporate governance issues concerning the board of directors (CGDBD) is associated with an 82 percent increase in bank performance (ROA), all other variables held constant. 
Similarly, Model 1C indicates that a one-percent increase in the disclosure level of corporate governance matters of the board of directors (CGDBD) leads to an increase of 82 kobos (or 82 percent increase) in bank performance proxy of EPS. A one-percent increase in the CGDBD is associated with a 48 percent increase in ROE in Model 1B, ceteris paribus. The findings are consistent with prior studies on the effect of corporate governance and its disclosure on firm performance (See: (Achoki, Kule, and Shukla, 2016; Jiao, 2011; Ntim, Kwaku, and Danbolt, 2012)). The CGDBD signals alignment commitment with international best practices and acts as managerial incentives for the banks. This finding is not surprising since the responsibility for ensuring good corporate governance rests with the board just as it is held responsible for poor performance and corporate failures (Agrawal and Chadha, 2005). Indeed, the crucial role of the board of directors in the organizational survival and systemic role of banks is such that regulators take serious umbrage at insider-related corporate governance infractions. The regulatory exceptions often lead to the dismissal of the board, as was the case with some Nigerian banks in 2009 (See: (Sanusi, 2010; Herbert, Onyilo, Ene and Tsegba, 2017; Herbert, Tsegba, Ene. and Onyilo, 2017)), and the latest CBN's action against the board of First Bank of Nigeria Limited and its parent company, FBN Holdings Plc. The result of this study further calls for effective and transparent boards in the management of banks to command the trust and confidence of stakeholders, depositors, and customers.

Risk is important for any organization, more so for banks. Banks are exposed to some risks including operational, credit, liquidity, market, and sovereign risks. Overexposure or improperly managed risks can lead to chaos, crisis, and bank failure with disastrous consequences for depositors and the economy as a whole. This partly explains why banks are highly subjected to prudential guidelines and regulations. The ability of a bank to prudently manage its risks translates into its capacity to help its customers manage their risk exposures which, in turn, helps the bank to sustain fewer loan losses and improve profits. The results of models $2 \mathrm{~A}, 2 \mathrm{~B}$, and $2 \mathrm{C}$ substantiate a positive effect of disclosure of risk management framework on firm performance. The effect is not significant perhaps due to weak or nondurable risk management system to fully capture the intricate risk factors, such as political risks or risks associated with lending to politically exposed persons. The rising cases and structure of nonperforming loans (NPLs) in Nigerian banks lend credence to this viewpoint.

Models 3A, 3B, and 3C present a positive and significant association between the disclosure of whistle-blowing policy and the financial performance of banks. In Model 3A, for a one percent increase in the disclosure level of the whistle-blowing policy, the ROA increases by $50 \%$, ceteris paribus. Models $3 \mathrm{~B}$ and $3 \mathrm{C}$ buttress the evidence that an increase in disclosure of whistle-blowing policy is strongly associated with an increase in ROE and EPS, ceteris paribus. This supports Bushman, Piotroski, and Smith's (2004) perspective on the value relevance of corporate transparency. An effective whistleblowing policy can mitigate unethical practices in the banking industry and boost corporate performance.

Across the models, the study finds that bank size is useful in explaining the link between corporate governance disclosure and financial performance. This is consistent with the empirical findings that large firms have better opportunities and can quickly muster sufficient resources to install and implement robust disclosure mechanisms (Fanta, Kemal, and Waka, 2013; Madhani, 2016a, b). Madhani (2016a) found a statistically significant difference between corporate governance and disclosure practices of large firms and small Indian firms with the conclusion that corporate governance and disclosure practices of large firms are better than those of small firms.

The role of block shareholdings coheres with the evidence of mixed results of Isshaq, Bokpin, and Mensah (2009). The authors found a significantly positive relationship between board size and share price among the corporate governance variables but found none between inside ownership and share price. A few comments on block shareholding may help elucidate its inconsistent role and account for the inconsistent result across the models. The nexus between corporate ownership and corporate performance remains a contentious issue in corporate governance, corporate law, and institutional economics. The ownership-performance-debate (OPD) is of special interest in emerging and transition economies where wholesale privatization and commercialization of state-owned enterprises (SOEs) 
are crucial aspects of economic reforms (Tsegba, Herbert and Ene, 2014). To be sure, economic reforms of the privatization genre have implications for ownership structure and control, corporate governance, and corporate performance. This is the context in which the discriminating properties of concentrated ownership, foreign ownership or block-holder ownership, or core/strategic investor ((Tsegba and Herbert, 2013b) can be discerned. The distinguishing feature of these ownership structures is the size of the ownership stake, which imbues both the government incentives and capacity to engage in economic transactions. For example, a large stake in the form of strategic/core investor ${ }^{2}$, foreign ownership, concentrated, block-holding, or block shareholder ownership, entitles more voting rights, more clout and greater say in policymaking, governance structure, and managerial influence.

\section{Conclusions}

Over the years, corporate governance disclosure has become a key part of business practice and has precipitated a powerful trend around the world, especially for banks and oil companies whose operational activities impinge on people's lives and livelihoods. Thus, using the firms' CG reports to assess their corporate performance is an affirmative empirical attempt at improving corporate governance reporting as well as the firm's image. Corporate governance disclosures paint a positive picture of the company's ecosystem. In general, effective or progressive corporate governance practice enables the directors to take responsibility for their decisions and the performance of their organizations as a whole. It enables them to have a clear organizational strategy, effective risk management, discipline and commitment, proper attention to employees and customers, corporate transparency and information sharing, corporate social responsibility, and regular self-evaluations to identify and mitigate brewing problems. Above all, progressive corporate governance leverages individual executives and enhances corporate trust and reputation

This study examines the effect of CGD on the financial performance of banks listed on the Nigerian Stock Exchange (NSE) from 2011 to 2016. We further develop a disclosure checklist as a research instrument to collect the CG data. The checklist is anchored on the provisions of the 2014 Codes of Corporate Governance of the Central Bank of Nigeria (CBN-CCG) for banks and finance houses and 2011 Securities and Exchange Commission (SEC-CCG)) for the capital market. We also use content analysis to extract CG data from 78 annual reports of 13 commercial banks. We then construct three corporate governance disclosure indices (CGDI), namely: CGDI on board of directors, CGDI on risk management framework, and CGDI on whistle-blowing policy. We then formulate and test 10 hypotheses (condensed into four) using, OLS method of multiple regressions. The research findings have policy implications for banks and stakeholders, especially regulators. For banks, the study calls for (i) an increase in CGD in their annual reports, and (ii) a disaggregation of CGD to enhance transparency and understanding. For regulators, the study advocates for (a) regulatory reassessment of the disclosure requirements in the risk management framework to ensure that every aspect of risk is captured, especially political risks; regulatory requirement regarding whistleblowing policy and the disclosure thereof; and (b) regulatory enforcement of the disclosure requirements by imposing stiffer penalties on contraventions. Progressive corporate governance practice (with disclosure) is neither a nontrivial nor costless organizational activity (See also: (Baumann and Nier (2004)). Effective and transparent boards of banks engender the trust and confidence of regulators, stakeholders, depositors,

2 The concept of a 'core/strategic investor' has not received any meaningful attention in the literature of corporate governance and ownership structure and control even though it has, indeed, been practiced in some jurisdictions. For instance, in China, listed companies normally have one ultimate owner who holds a significant percentage of total shares and control of their operations (Bai, Liu, Lu, Song, and Zhang, 2005). The concept resonates with the Nigerian privatization programmed Conceptually, core investors are perceived as economic agents who possess the simultaneous complementarity of three key attributes: (a) technical know-how concerning the activities of the enterprise they wish to invest in; (b) financial muscle, not only to pay a competitive price for the enterprise they wish to buy into but also to turn around its fortune, using their resources without relying on the Government for funds; and (c) managerial know-how to run the enterprise profitably in a competitive business environment dictated by market forces. These attributes provide the bureaucratic insularity needed to obviate (a) the manifestation of bureaucratic opportunism, and (b) the adverse consequences of the separation of ownership and control in the privatized firm. Put simply, core investors are those that have or must-have, the entrepreneurial bent, mechanisms, and incentives to own and manage the privatized enterprises (Tsegba and Herbert, 2011). 
and customers. Finally, good corporate governance practice contributes not only to corporate sustainability but also to the sustainable development of the economy.

While a bank can manipulate the information disclosed, deliberately complicate the information content, make it prohibitively costly to discern, or create uncertainty when to disclose information and thus affect its decision-usefulness by investors and other stakeholders (Refait-Alexandre, Farvaque, Gainet and Saïdane, 2009), the difficult conundrum of inefficient markets is inextricably implied. This presumption is a trend that is prevalent in SSA. In SSA jurisdictions, where regulatory institutions are both corrupt and weak and bounded rationality challenges are rife amidst environmental factors of uncertainty, opportunism, and small-numbers exchange relations (Williamson, 1975; Herbert, 2019), transforming information communicated by the company into usable knowledge by investors, regulators and wider stakeholders require a great deal of work and if disclosure makes this work less profitable for financial analysts and informed agents, this will prospectively reduce or attenuate the overall knowledge of the company. On the other hand, Refait-Alexandre, Farvaque, Gainet and Saïdane (2009) argue that as some investors are better informed and better able to discern and process information than others, a phenomenon of bounded rationality, disclosure can increase the information impacted news problem that exists among the different stakeholders (See also: (Wagenhofer, 2004)). When, therefore, third party stakeholders have information disparity under the atmosphere of corporate disclosure (that is, while companies display a disclosure policy), stakeholders may be victims of a knowledge illusion, whereby they think they have full knowledge of the company while that is not the case (Refait-Alexandre, Farvaque, Gainet and Saïdane, 2009).

The associated market/investor behavior may exacerbate financial market instability, increase the risks of information bubbles, and worsen their consequences when the bubbles burst. Anecdotal evidence points to this elusive market performance in SSA countries where both regulators and the regulated (operators) are participants in the same markets, or dominant market presence of unlawful monopolization is explicit. Nigeria and other SSA countries are bedeviled by these challenges juxtaposing corruption, weak political and economic governance, and institutional lethargy and weakness. First, the moral compass of accountability and transparency in these countries suffers from a serious deficit. This is the culture in which codes of corporate governance and disclosure practices are practiced. Second and related, board appointments in banks follow the same jaundiced trajectory of adverse selection with consequential moral hazards. Third, the prevailing evidence of regulatory capture in Nigeria's financial sector is a moral hazard consequence of adverse selection. This milieu cannot engender progressive corporate governance; instead, it weakens institutional capacity which obfuscates disclosure. These are some of the regulatory and policy challenges implicit in governance disclosure. A conclusive suggestion canvasses greater empirical assessment of the economic consequences of corporate governance disclosure in emerging economies.

As with most empirical studies, this study is not without its limitations, despite its contribution to knowledge. However, these limitations also are interesting and fruitful avenues for future research. First, the dimensions of corporate governance are an evolving phenomenon of empirical research, especially in SSA. The implication is that no study can claim a significant level of comprehensiveness in covering the phenomena of interest. Second, the study sample was limited to Nigerian commercial banks, the stylized deposit money banks. A more robust or inclusive approach will be an evaluation of CG disclosure practices of banks and discount houses since the CBN-CCG codes encompass banks and discount houses. Also, a comparative analysis of the CG disclosure and corporate performance of Nigerian banks and discount houses will be a useful avenue. This study is limited to three measures of profitability angle of accounting returns which also provide a stock market evaluation of firm (bank) performance. Firm performance is measured by return on assets (ROA), return on equity (ROE), and earnings per share (EPS). Both ROA and ROE are accounting performance measures while EPS is a market-based performance measure. While the accounting performance measures are more appropriate for firms pursuing share-increasing and turnaround business investment strategies, both accounting and market-based measures are more appropriate for firms pursuing less risky profitoriented business investment strategies (Wayne and Jones, 1996). Because corporate performance is a 
complex construct in strategic management and accounting and finance, research dimensionalizes the praxes of performance measurement to include accounting returns (profitability and liquidity dimensions), growth, and stock market performance (Hamann, Schiemann, Bellora, and Guenther, 2013). The acknowledgment of these broader dimensions of corporate performance is a limitation of this study but also opens vistas of future research.

\section{Appendix 1: Sampled Nigerian Deposit Money Banks (DMBs)}

\begin{tabular}{|c|c|}
\hline S/N & DEPOSIT MONEY BANK \\
\hline 1 & Access Bank Plc \\
\hline 2 & Diamond Bank Plc \\
\hline 3 & FBN Holdings Plc \\
\hline 4 & Fidelity Bank Plc \\
\hline 5 & FCMB Group Plc \\
\hline 6 & Guaranty Trust Bank Plc \\
\hline 7 & Stanbic IBTC Holdings Plc \\
\hline 8 & Sterling Bank Plc \\
\hline 9 & Union Bank of Nigeria Plc \\
\hline 10 & United Bank for Africa Plc \\
\hline 11 & Unity Bank Plc \\
\hline 12 & Wema Bank Plc \\
\hline 13 & Zenith Bank Plc \\
\hline
\end{tabular}

\section{APPENDIX 2: Corporate Governance Disclosure Checklist}

\begin{tabular}{|c|c|c|}
\hline $\mathbf{S} / \mathbf{N}$ & GROUP & CORPORATE GOVERNANCE DISCLOSURE ITEMS \\
\hline \multicolumn{2}{|c|}{ CGBDB } & Corporate Governance Disclosure on Board of Directors \\
\hline 1 & CGDBD & Whether the roles of chairperson and CEO/MD are split. \\
\hline 2 & CGDBD & Whether the chairperson of the board is a non-executive director. \\
\hline 3 & CGDBD & Whether the board is composed of a majority of non-executive directors (NEDs). \\
\hline 4 & CGDBD & How often does the board meet? Whether the board meets at least four times in a year. \\
\hline 5 & CGDBD & Whether the records of individual directors' meetings are disclosed. \\
\hline 6 & CGDBD & Whether directors are classified into executive directors, NED, and independent directors. \\
\hline 7 & CGDBD & Whether the board's evaluation report is disclosed. \\
\hline 8 & CGDBD & Whether directors' biography and experience are disclosed. \\
\hline 9 & CGDBD & Whether share ownership by all insiders is disclosed \\
\hline 10 & CGDBD & Whether a nomination committee has been established. \\
\hline 11 & CGDBD & Whether the nomination committee consists of a majority of NEDs. \\
\hline 12 & CGDBD & Whether the chairperson of the nomination committee is a NED. \\
\hline 13 & CGDBD & Whether the members of the nomination committee are disclosed. \\
\hline 14 & CGDBD & Whether the nomination committee's members' meetings attendance record is disclosed. \\
\hline 15 & CGDBD & Whether a remuneration committee has been established. \\
\hline 16 & CGDBD & Whether the remuneration committee is constituted entirely by independent NEDs. \\
\hline 17 & CGDBD & Whether the chairperson of the remuneration committee is an independent NED. \\
\hline 18 & CGDBD & Whether the members of the remuneration committee are disclosed. \\
\hline 19 & CGDBD & Whether the remuneration committee's members' meetings attendance record is disclosed. \\
\hline 20 & CGDBD & $\begin{array}{l}\text { Whether a firm's board is formed by at least one male and one female (board diversity } \\
\text { based on gender) person. }\end{array}$ \\
\hline 21 & CGDBD & Whether bank succession plan for their top executives is disclosed \\
\hline 22 & CGDBD & Whether the board of directors has at least two independent NED. \\
\hline
\end{tabular}




\begin{tabular}{|c|c|c|}
\hline \multicolumn{3}{|r|}{ CGDRF: Corporate Governance Disclosure on Risk Framework } \\
\hline 1 & CGDRF & Whether an audit committee has been established. \\
\hline 2 & CGDRF & Whether the audit committee is constituted by NEDs and shareholders representatively. \\
\hline 3 & CGDRF & Whether the chairperson of the audit committee is a shareholder representative. \\
\hline 4 & CGDRF & Whether the members of the audit committee are disclosed. \\
\hline 5 & CGDRF & $\begin{array}{c}\text { Whether the members of the audit committee are split equally between shareholders and } \\
\text { directors. }\end{array}$ \\
\hline 6 & CGDRF & Whether the audit committee's members' meetings attendance record is disclosed. \\
\hline 7 & CGDRF & Whether a risk management committee has been established. \\
\hline 8 & CGDRF & Whether the risk committee's members' meetings attendance record is disclosed. \\
\hline 9 & CGDRF & $\begin{array}{l}\text { Whether a narrative on both actual and potential future systematic and non-systematic } \\
\text { risks is disclosed. }\end{array}$ \\
\hline 10 & CGDRF & Whether a narrative of the risk framework is disclosed. \\
\hline 11 & CGDRF & Whether the existence of a Chief Risk Officer is disclosed \\
\hline 12 & CGDRF & $\begin{array}{l}\text { Whether a narrative of the procedures and processes for identification, measurement, } \\
\text { monitoring, control, and reporting of the current and future risks is disclosed. }\end{array}$ \\
\hline 13 & CGDRF & $\begin{array}{l}\text { Whether a narrative on the actual measures taken by a firm to address occupational } \\
\text { health and safety of its employees is disclosed. }\end{array}$ \\
\hline 14 & CGDRF & Whether the bank's handling of consumer complaints is disclosed. \\
\hline 15 & CGDRF & Whether a credit committee has been established. \\
\hline 16 & CGDRF & Whether the chairperson of the credit committee is a NED. \\
\hline 17 & CGDRF & Whether the members of the credit committee are disclosed. \\
\hline 18 & CGDRF & Whether the credit committee's members' meetings attendance record is disclosed. \\
\hline 19 & CGDRF & Whether corporate governance compliance status is disclosed \\
\hline 20 & CGDRF & Whether related party transactions are disclosed \\
\hline 21 & CGDRF & Whether regulatory/supervisory contraventions are disclosed \\
\hline 22 & CGDRF & Whether regulatory penalties and sanctions are disclosed \\
\hline 23 & CGDRF & Whether frauds and forgeries are disclosed \\
\hline \multicolumn{3}{|r|}{ CGDWBP: Corporate Governance Disclosure on Whistleblowing Policy } \\
\hline 1 & CGDWBP & Whether the bank whistle-blowing policy is disclosed. \\
\hline 2 & CGDWBP & Whether a narrative on the existence of a code of ethics is disclosed. \\
\hline 3 & CGDWBP & Whether a narrative of bank whistleblowing procedure is disclosed \\
\hline 4 & CGDWBP & $\begin{array}{l}\text { Whether a narrative that the bank whistle-blowing policy is appropriately communicated } \\
\text { to all employees is disclosed. }\end{array}$ \\
\hline 5 & CGDWBP & $\begin{array}{l}\text { Whether a narrative of declaration of management and board commitment to the } \\
\text { whistleblowing policy is disclosed }\end{array}$ \\
\hline 6 & CGDWBP & Whether the objectives of the whistleblowing policy are disclosed \\
\hline 7 & CGDWBP & Whether an analysis of whistleblowing cases is disclosed \\
\hline 8 & CGDWBP & Whether a hotline and/or dedicated email for complaint is disclosed \\
\hline 53 & & Overall Total of Corporate Governance Checklist Items \\
\hline
\end{tabular}

Notation: CGDBD = Corporate Governance Disclosure on Board of Directors; CGDWBP = Corporate Governance Disclosure on Whistle Blowing policy; CGDRF = Corporate Governance Disclosure on Risk Framework

Author Contributions: The authors contributed equally to the development of the paper. The authors have read and agreed to the published version of the manuscript.

Funding: This research received no external funding.

Acknowledgments: We would like to acknowledge the helpful comments of the editor and the reviewers of this paper. 
Conflicts of Interest: The authors declare no conflict of interest.

\section{References}

Achoki, I. N., Kule, J. W., \& Shukla, J., (2016). Effect of voluntary disclosure on the financial performance of commercial banks in Rwanda: A study on selected banks in Rwanda. European Journal of Business and Social Sciences, 5(6), 167-184.

Agrawal, A., \& Chadha, S. (2005). Corporate governance and accounting scandals. The Journal of Law and Economics, 48(2), 371-406.

Al-Akra, M., \& Ali, M. J. (2012). The value relevance of corporate voluntary disclosure in the Middle East: the case of Jordan. Journal of Accounting and Public Policy, 31(5), 533-549. https://doi.org/10.1016/j.jaccpubpol.2011.10.007.

Arun, T. G., \& Turner, J.D. (2002a). Corporate governance of banks in developing. Advisory Group on Corporate Governance (AGCG) Report on Corporate Governance and International Standards, Reserve Bank of India.

Arun, T.G. \& Turner, J. D. (2002b). Corporate governance of banking institutions in developing economies: The Indian experience. Paper presented in the Conference of Finance and Development organized by IDPM, University of Manchester, July.

Baek, J-S., Kang, J-K. \& Park, K. S. (2004). Corporate governance and firm value: Evidence from the Korean financial crisis. Journal of Financial Economics, 71(2), 265-313.

Bai, C., Liu, Q., Lu, J., Song, F. M., \& Zhang, J. (2005). An Empirical Study of Corporate Governance and Market Valuation in China. Economic Research Journal, 2, 84-110.

Bamber, L. S., Jiang, J. X., \& Wang, I. Y. (2010). What's My Style? The Influence of Top Managers on Voluntary Corporate Financial Disclosure. The Accounting Review, 85(4), 1131-1162. https://doi.org/10.2308/accr. 2010.85.4.1131

Barako, D.G. (2007). Determinants of voluntary disclosure in Kenyan companies' annual reports. African Journal of Business Management, 1(5), 113-128.

Barako, D. G., \& Tower, G. (2006). Corporate Governance and Bank Performance: Does Ownership Matter? Evidence from Kenyan Banking Sector. Corporate Ownership and Control, 4(2), 133-144.

Barros, C. P., \& Caporale, G. M. (2012). Banking Consolidation in Nigeria, 2000-2010. Journal of African Business, 13(3), 244-252. https://doi.org/10.1080/15228916.2012.727756.

Baumann, U., \& Nier, E. (2004). Disclosure, volatility, and transparency: an empirical investigation into the value of bank disclosure. FRBNY Economic Policy Review, 10(2), 31-45.

Beekes, W., \& Brown, P. (2006). Do Better-Governed Australian Firms Make More Informative Disclosures? Journal of Business Finance \& Accounting. 33(3-4), 422-450. https://doi.org/10.1111/j.1468-5957.2006.00614.x.

Bhasin, M. L. (2010). Corporate governance disclosure practices: The portrait of the developing country. International Journal of Business and Management, 5(4), 150-167.

Botosan, C. (1997). Disclosure Level and the Cost of Equity Capital. The Accounting Review, 72(3), 323-349.

Brown, L. D., \& Caylor, M. L. (2006). Corporate Governance and Firm Valuation. Journal of Accounting and Public Policy, 25(4), 409-434.

Bujaki, M., \& McConomy, B. J. (2002). Corporate Governance: Factors Influencing Voluntary Disclosure by Publicly Traded Canadian Firms. Canadian Accounting Perspectives, 1(2), 105-139. https://doi.org/ $\underline{10}$. 1506/9FN9-ECC9-7GL7-25NT.

Bushman, R. M., Piotroski, J. D., \& Smith, A. J. (2004). What determines corporate transparency? Journal of Accounting Research, 42(2), 207-252.

Cadbury, A. (1990). The Company Director, Director Books.

Cadbury, A. (2000). The Corporate Governance Agenda. Corporate Governance, 8(1), 7-15.

Camfferman, K., \& Cooke, T. E. (2002). An analysis of disclosure in the annual reports of U.K. and Dutch Companies. Journal of International Accounting Research, 1, 3-30.

Central Bank of Nigeria (CBN) (2006). Code of Corporate Governance for Banks in Nigeria Post-consolidation. CBN. https://www.cbn.gov.ng

Central Bank of Nigeria (CBN) (2014). Code of Corporate Governance for Banks and Discount Houses in Nigeria. CBN. https://www.cbn.gov.ng

Collett, P. \& Hrasky, S. (2005). Voluntary Disclosure of Corporate Governance Practices by Listed Australian Companies. Corporate Governance: An International Review, 13(2), 188-196. https://doi.org/10.1111/ j.1467-8683.2005.00417.x

Darnall, N., Henriques, I., \& Sadorsky, P. (2010). Adopting proactive environmental strategy: the influence of stakeholders and firm size. Journal of Management Studies, 47(6), 1072-1094. 
Daske, H. \& Gebhardt, G. (2006). International financial reporting standards and experts' perceptions of disclosure quality. Abacus, A Journal of Accounting, Finance, and Business Studies, 42(3-4), 461-498. https://doi.org/10.1111/j.1467-6281.2006.00211.x

DeFond, M., Hann R. H., \& Hu, X., (2005). Does the market value financial expertise on audit committees of boards of directors? Journal of Accounting Research, 43(2),153-93.

Dembo, A. M., \& Rasaratham, S. (2014). Corporate governance and disclosure in Nigeria: An empirical study. Procedia Social and Behavioural Sciences, 164, 161-174.

Dockery, E., \& Herbert, W. E. (2000a). Perspectives on Corporate Governance: Editorial Note. Managerial Finance, 26(9), 1-2.

Dockery, E., \& Herbert, W. E. (2000b). Corporate governance and enterprise restructuring in transition economies: Evidence from Privatised Polish companies. Managerial Finance, 26(9), 80-92. https://doi.org/10.1108/03074350010766891

Dockery, E., Herbert, W. E., \& Taylor, K. (2000). Corporate Governance, Managerial Strategies, and Shareholder Wealth Maximisation: A Study of Large European Companies. Managerial Finance, 26(9), 21-35. https://doi.org/10.1108/03074350010766855

Dockery, E., Tsegba, I. N., \& Herbert, W. E. (2013). Does Ownership Structure Influence Firm Performance? Empirical Insights from an Emerging Market. Journal of Governance and Regulation, 1(4), 165-175. https://doi.org/10.22495/jgr v1 i4 c1 p4

Emmanuel, U. O., \& Sabastian, S. M. (2015). Corporate governance disclosure practices and bank performance in Nigeria: An empirical investigation. International Journal of Managerial Studies and Research, 3(1), 49-56.

EWMI/PFS Program (2005). Lectures on Corporate Governance - Three Models of Corporate Governance, Dec. 2005.doc. https://www.emergingmarketsesg.net->Three-Models-of-Corporate-Governance-January-2009.pdf

Fanta, A. B., Kemal, K. S., \& Waka, Y. K. (2013). Corporate Governance and impact on Bank Performance. Journal of Finance and Accounting, 1(1), 19-26. https://doi.org/10.11648/j.jfa.20130101.12

Fernando, S. \& Lawrence, S. (2014). A theoretical framework for CSR practices: Integrating legitimacy theory, stakeholder theory, and institutional theory. Journal of Theoretical Accounting Research, 10, 149-178.

Financial Reporting Council of Nigeria (FRCN) (2018). Nigerian Code of Corporate Governance (NCCG). FRCN.

Glen, S. (2018). Tolerance Level/Tolerance Statistics: Definition, Examples from Statistics HowTo.com: Elementary Statistics for the rest of us!

Gray, R., Kouhy, R., \& Lavers, S. (1995). Methodological themes: Constructing a research database of Social and Environmental Reporting by UK companies. Accounting, Auditing and Accountability Journal, 8(2), 78-101.

Gray, S. J., Shaw, J. C., \& McSweeney, L. B. (1981). Accounting Standards and Multinational Corporations. Journal of International Business Studies. 12, 121-136. https://doi.org/10.1057/palgrave.jibs.8490574

Gujarati, D. N., \& Sangeetha, N. (2007). Basic Econometrics. McGraw-Hill International Edition.

Gyamerah, S., Amo, H. F., \& Adomako, S. (2020). Corporate governance and the financial performance of commercial banks in Ghana. Journal of Research in Emerging Markets, 2(4), $33-47$. https://doi.org/10.30585/jrems.v2i4.541

Hackston, D. \& Milne, M. J. (1996). Some Determinants of Social and Environmental Disclosures in New Zealand Companies. Accounting, Auditing \& Accountability Journal, 9, 77-108. https://dx.doi.org/10.1108/09513579 610109987

Hamann, P. M., Schiemann, F., Bellora, L. \& Guenther, T. W. (2013). Exploring the Dimensions of Organizational Performance: A Construct Validity Study. Organizational Research Methods, 16(1), 67-87. https://doi.org/10.1177/1094428112470007

Haniffa, R. M., \& Cooke, T. E. (2002). Culture, Corporate Governance, and Disclosure in Malaysian Corporations, Abacus. A Journal of Accounting, Finance, and Business Studies, 38(3), 317-349. https://doi.org/10.1111/1467$\underline{6281.00112}$

Hassan, O. A. G., Romilly, P., Giorgioni, G., \& Power, D. (2009). The value relevance of disclosure: Evidence from the emerging capital market of Egypt, The International Journal of Accounting, 44, 79-102.

Healy, P. M., \& Palepu, K.G. (1993). The effect of firms' financial disclosure strategies on stock prices. Accounting Horizons, 7, 1-11.

Healy, P. M., \& Palepu, K. G. (2001). Information asymmetry, corporate disclosure, and the capital markets: A Review of the empirical disclosure literature. Journal of Accounting and Economics, 31(1-3), 405-440. https://doi.org/10.1016/S0165-4101(01)00018-0

Herbert, W. E. (1987). An Analysis of Issues Related to Transnational Disclosure (Unpublished MAcc Dissertation). University of Glasgow, Scotland, UK.

Herbert, W. E. (1995). Alternative Strategies to Foreign Investment. UMI 
Herbert, W. E. (1996). Alternative Research Paradigm in Accounting and Finance: The Case for Responsive Focusing. Management Research News, 19(3), 1-21. https://doi.org/10.1108/eb028440

Herbert, W. E. (2001). The Relations between Corporate Governance, Managerial Strategies \& Shareholder Value Creation: An International Analysis, Accounting Frontier, 3(1): 1 - 24.

Herbert, W. E. (2019). Hindsight, Foresight, and Insight into Global Corruption Issues. Journal of Forensic and Investigative Accounting, 11(1) (January-June), 81-102.

Herbert, W. E., Nwaorgu, I. A., Onyilo, F., \& Iormbagah,' J. A. (2020). Sustainability Reporting and Performance of Listed Upstream Oil and Gas Firms in Nigeria: A Content Evaluation Approach. International Journal of Applied Economics, Finance, and Accounting, 8(1), 46-61. https://doi: 10.33094/8.2017.2020.81.46.61

Herbert, W. E., Onyilo, F., Ene. E. E., \& Tsegba, I. N. (2017). Fraud and Forensic Accounting Education in Nigeria: Prospects and Challenges. International Journal of Business and Management, 12(7), 146-161. https://doi.org/10.5539/ijbm.v12n7p146

Herbert, W. E. \& Tsegba, I. N. (2011). Corporate Governance and Firm Performance through Ownership Structure of Nigerian Listed Companies. Journal of Business and Financial Studies, 3(1): 1-27.

Herbert, W. E., Tsegba, I. N., Ene. E. E. \& Onyilo, F. (2017). The Rise of Fraud Examination and Forensic Accounting in Africa: The Nigerian Experience. Archives of Business Research, 5(4):1-18.

Ho, S. S. M., \& Wong, K. S. (2001). A study of the relationship between corporate governance structures and the extent of voluntary disclosure. Journal of International Accounting, Auditing E Taxation, 10(2),139-156.

Huber, C., Leape, S., Mark, L., \& Simpson, B. (2020). The board's role in embedding corporate purpose: Five actions directors can take today. Strategy \& Corporate Finance, McKinsey \& Company, November. https://www.mckinsey.com/

Isshaq, Z., Bokpin, G. A., \& Mensah, O. J. (2009). Corporate governance, ownership structure, cash holdings, and firm value on the Ghana Stock Exchange. Journal of Risk Finance, 10(5), 488-499. https://doi.org/10.1108/15265940911001394

Jennings, R., \& Starks, L. (1985). Information Content and the Speed of Stock Price Adjustment. Journal of Accounting Research, 23(1), 336-350. https://doi.org/doi:10.2307/2490922

Jensen, M. C. \& Meckling, W. H. (1976). Theory of the firm: managerial behavior, agency costs, and ownership structure. Journal of Financial Economics, 3(October), 305-360.

Jiao, Y. (2011). Corporate Disclosure, Market Valuation, and Firm Performance. Financial Management, $40(3), 647-$ 676. https://doi.org/10.1111/j.1755-053X.2011.01156.x

Kohlbeck, M., \& Mayhew, B. W. (2010). Valuation of firms that disclose related party transactions. Journal of Accounting and Public Policy, 29, 115-137.

Lang M., Lins, K.V. \& Miller, D. (2003). ADRs, Analysts, and Accuracy: Does Cross Listing in the US Improve a Firm's Information Environment and Increase Market Value? Journal of Accounting Research, 41, 317-346.

Madhani, P. M. (2016a). Firm Size, Corporate Governance and Disclosure Practices: Interrelations, SCMS Journal of Indian Management, 13(2), 17-39.

Madhani, P. M. (2016b). Study of Corporate Governance and Disclosure Practices: Old Economy versus New Economy Firms, Great Lakes Herald, September 10(2), 1-25.

Mckinnon, J. L. \&Dalimunthe, L. (1993). Voluntary disclosure of segment information by Australian diversified companies. Accounting and Finance, 23 (1), 33-50.

McKinsey \& Company (Hunt, V., Simpson, B., \& Yamada, Y.) (2020). The case for stakeholder capitalism. McKinsey \& Company. https://www.mckinsey.com/

Meek, G., Roberts, C., \& Gray, S. (1995). Factors Influencing Voluntary Annual Report Disclosures by U.S., U.K. and Continental European Multinational Corporations. Journal of International Business Studies, 26(3), 555-572. https://www.jstor.org/stable/155561.

Meulbroek, L. K., (2002). Integrated risk management for the firm: A senior manager's guide, Journal of Applied Corporate Finance, 14, 56-70.

Micelli, M.P., \& Near, J.P. (1992). Blowing the Whistle. The Organizational and Legal Implications for Companies and Employees. New York: Macmillan Inc.

Micelli, M.P., Near, J.P., \& Dworkin, T.M. (2008). Whistleblowing in Organizations. New York: Routledge.

Mitton, (2002). A cross-firm analysis of the impact of corporate governance on the East Asian financial crisis. Journal of Financial Economics, 64(2), 215-241.

Ntim, C. G., Kwaku, K. O. \& Danbolt, J. (2012). The relative value relevance of shareholder versus stakeholder corporate governance disclosure policy reforms in South Africa. Corporate Governance: An International Review, 20(1), 84-105.

OECD (Organisation for Economic Cooperation and Development) (1999). Principles of Corporate Governance, OECD. 
OECD (2004). Principles of Corporate Governance. OECD. www.oecd.org/daf/governance/principles/ Html.

Othman, H. B. (2012). The effect of board structure and process disclosure on corporate performance in the emerging African markets. Managerial Auditing Journal, 27(2): 156-174.

Owusu-Ansah, S. (1998). The impact of corporate attributes on the extent of mandatory disclosure and reporting by listed companies in Zimbabwe. The International Journal of Accounting, 33(5), 605-631.

Refait-Alexandre, C., Farvaque, E., Gainet, C., \& Saidane, D. (2009). Is Corporate Disclosure Necessarily Desirable? A Survey. Paris December Finance International Meeting AFFI-EUROFIDAI. https://dx.doi.org/10.2139/ssrn.1494238

Robert, A. (2014). Whistle-blowing and employee loyalty. Journal of Business Ethics, 11(2), 3-7.

Samaha, K., \& Dahawy, K. (2011). An empirical analysis of corporate governance structures and voluntary corporate disclosure in volatile capital markets: The Egyptian experience. International Journal of Accounting, Auditing and Performance Evaluation, 7(1-2), 61-93

Samaha, K., Dahawy, K., Hussainey, K., \& Stapleton, P. (2012). The extent of corporate governance disclosure and its determinants in a developing market: The case of Egypt. Advances in Accounting, 28, 168-178. https://doi.org/10.1016/j.adiac.2011.12.001

Sanusi, L. S. (2010). The Nigerian Banking Industry: what went wrong and the way forward. Delivered at the Annual Convocation Ceremony of Bayero University, Kano, $3^{\text {rd }}$ January 2010.

Securities and Exchange Commission (SEC) (2003). Code of Best Practices for Public Companies. SEC.

SEC (2011). Code of Best Practices for Public Companies. SEC.

Sengupta, P. (1998). Corporate Disclosure Quality and the Cost of Debt, The Accounting Review, 73, 459-474.

Shrivastav, S. M. \& Kalsie, A. (2017). Corporate Governance Disclosure Index and Firm Performance: Evidence from NSE Companies, Business Analyst, 38(1), 173- 213.

Soyemi, K., Afolabi, O. V., \& Obigbemi, I. F. (2021). External audit quality and clients' corporate governance mechanisms in Nigeria: Any nexus?. Journal of Research in Emerging Markets, 3(2), 44-59. https://doi.org/10.30585/jrems.v3i2.596

Spence, M. (1973), Job Market Signalling. Quarterly Journal of Economics, 87, 355-374.

Spence, M. (2002), Signalling in Retrospect and the Informational Structure of Markets. American Economic Review, 92, 434-459.

Stachowicz-Stanusch, A. \& Wankel, C. (2011). Anti-Corruption Practices and Implementation Mechanisms of the Fortune Global 500 as an Answer for an Ethical Values Crisis - Research Results. Organization and Management 5(148): 139-155.

Street, D. L. \& Gray, S. I. (2002). Factors influencing the extent of corporate compliance with International Accounting Standards: Summary of a research monograph. Journal of International Accounting, Auditing $\mathcal{E}$ Taxation 11, 51-76.

Subramanian, S., \& Reddy, V. N. (2012). Corporate governance disclosures and international competitiveness: A study of Indian firms. Asian Business EManagement, 11(2), 195-218.

Suchman, M. (1995). Managing Legitimacy: Strategic and Institutional Approaches. Academy of Management Review, 20, 571-611. https://doi.org/10.2307/258788

Tsegba, I. N. \& Herbert, W. E. (2011). The Relationship between Ownership Structure and Firm Performance: Evidence from Nigerian Listed Companies. African Journal of Accounting, Economics, Finance and Banking Research, 7(7), 51-63.

Tsegba, I. N. \& Herbert, W. E. (2013a). Corporate Governance, Ownership Structure and Firm Performance in Nigeria. Research Journal of Finance and Accounting, 4(5), 23-38. https://doi.org/10.7176/RJFA

Tsegba, I. N. \& Herbert, W. E. (2013b). Core Investor Perspectives on Corporate Governance and Firm Performance. The Certified National Accountant, 21(1), 13-25 (January - March).

Tsegba, I. N., Herbert, W. E., \& Ene, E. E. (2014). Corporate Ownership, Corporate Control and Corporate Performance in Sub-Sahara Africa: Evidence from Nigeria. International Business Research, 7(11): 73-84. https://doi.org/10.5539/ibr.v7n11p73

United Nations Conference on Trade and Development (UNCTAD) (2003). Selected Issues in Corporate Governance: Regional and Country Experiences. United Nations New York and Geneva. https:/doi.org/ UNCTAD/ITE/TEB/2003/3

United Nations Global Compact (UNGC) (2009). Corporate Governance: The Foundation for Corporate Citizenship and Sustainable Business. New York: UNGC.

Verrecchia, R. E. (1983). Discretionary disclosures. Journal of Accounting and Economics, 5, 179-194. https://doi.org/10.1016/0165-4101(83)90011-3

Verrecchia, R. E. (2001). Essays on disclosure. Journal of Accounting and Economics, 32(1-3), 97-180. https://dx.doi.org/10.1016/S0165-4101(01)00025-8 
Vishwanath, T. and Kaufmann, D. (1999) Towards Transparency in Finance and Governance. New Approaches and Their Application to Financial Markets. The World Bank Research Observer, 16(1), 41-57.

Wagenhofer, A. (2004). Accounting and economics: What we learn from analytical models in financial accounting and reporting. In C. Leuz, D. Pfaff, \& A. Hopwood (Eds.), The Economics and Politics of Accounting Oxford: OUP.

Wallace, R. S. O. \& Naser, K. (1995). Firm-specific determinants of the comprehensiveness of mandatory disclosure in the corporate annual reports of firms listed on the Stock Exchange of Hong Kong. Journal of Accounting and Public Policy, 14, 311-368.

Wallace, R.S.O., Naser, K. \& Mora, A. (1994). The relationship between the comprehensiveness of corporate annual reports and firm characteristics in Spain. Accounting and Business Research, 25(97), 41-53.

Wayne, R. B. \& Jones, F. F. (1996). Business Investment Strategy and Firm Performance: A Comparative Examination of Accounting and Market-Based Measures. Managerial Finance, 22(8), 44-56. https://doi.org/10.1108/eb018576

Williamson, O. E. (1975). Markets and Hierarchies: Analysis and Antitrust Implications. The Free Press.

World Economic Forum (WEF) (2003) Corporate Governance. Strategic Intelligence. WEF.

World Economic Forum (WEF) (2020). 50th Annual Meeting in Davos: Defining Stakeholder Capitalism. WEF.

(C) 2020 by the authors. This article is an open-access article distributed under the terms and conditions of the Creative Commons Attribution (CC BY) license (http://creativecommons.org/licenses/by/4.0/). 